\title{
LEVEL II SCOUR ANALYSIS FOR BRIDGE 30 (BRIDTH00330030) on TOWN HIGHWAY 33, crossing DAILEY HOLLOW BRANCH, BRIDGEWATER, VERMONT
}

U.S. Geological Survey Open-File Report 96-304

Prepared in cooperation with

VERMONT AGENCY OF TRANSPORTATION and

FEDERAL HIGHWAY ADMINISTRATION 


\section{LEVEL II SCOUR ANALYSIS FOR BRIDGE 30 (BRIDTH00330030) on TOWN HIGHWAY 33, crossing DAILEY HOLLOW BRANCH, BRIDGEWATER, VERMONT}

By SCOTT A. OLSON and DONALD L. SONG

U.S. Geological Survey

Open-File Report 96-304

Prepared in cooperation with

VERMONT AGENCY OF TRANSPORTATION

and

FEDERAL HIGHWAY ADMINISTRATION 


\title{
U.S. DEPARTMENT OF THE INTERIOR BRUCE BABBITT, Secretary
}

\author{
U.S. GEOLOGICAL SURVEY \\ Gordon P. Eaton, Director
}

For additional information write to:

District Chief

U.S. Geological Survey 361 Commerce Way

Pembroke, NH 03275
Copies of this report may be purchased from:

U.S. Geological Survey Earth Science Information Center Open-File Reports Section Box 25286, MS 517 Federal Center

Denver, CO 80225 


\section{CONTENTS}

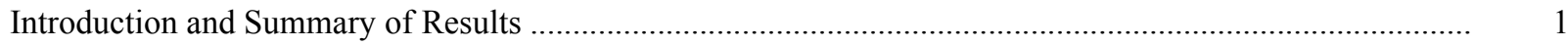

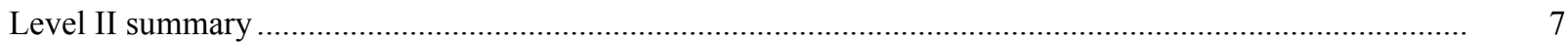

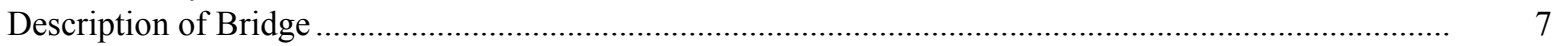

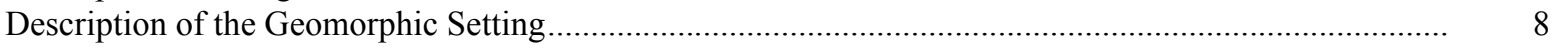

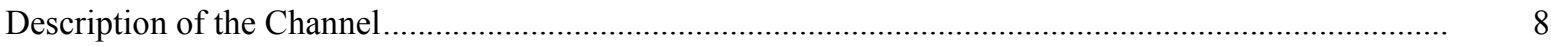

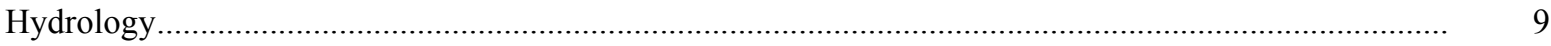

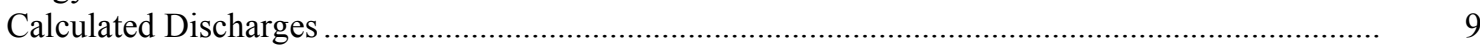

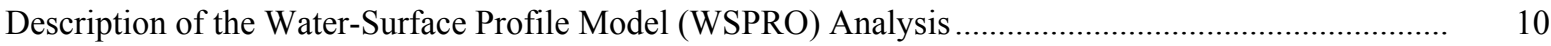

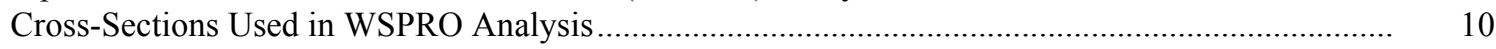

Data and Assumptions Used in WSPRO Model ...................................................................... 11

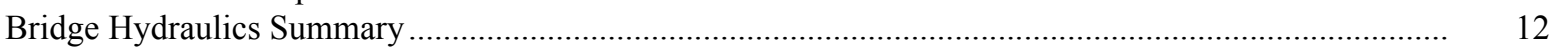

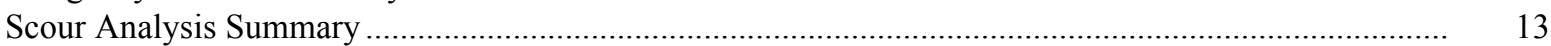

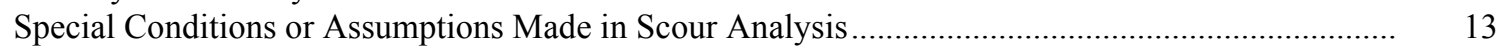

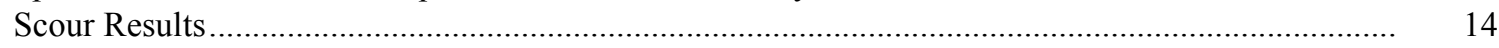

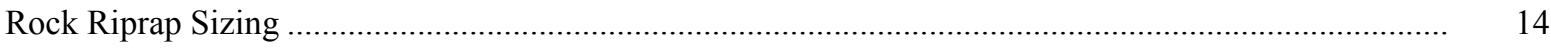

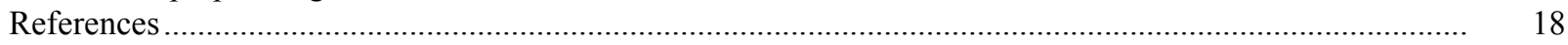

Appendixes:

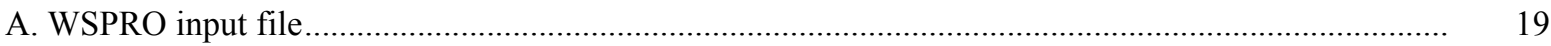

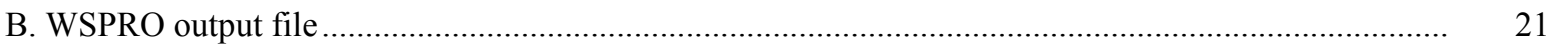

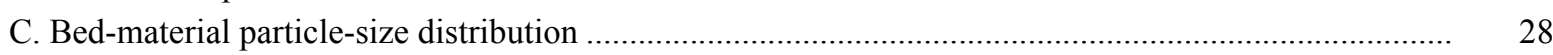

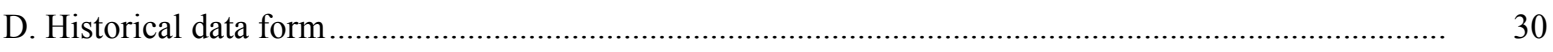

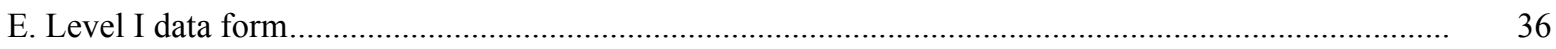

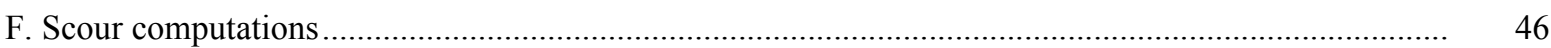

\section{FIGURES}

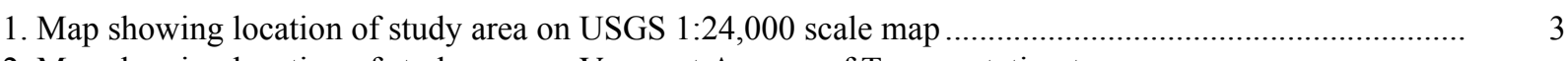

2. Map showing location of study area on Vermont Agency of Transportation town

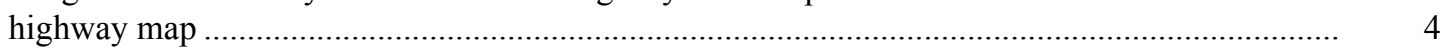

3. Structure BRIDTH00330030 viewed from upstream (November 1, 1994) .............................................. 5

4. Downstream channel viewed from structure BRIDTH00330030 (November 1, 1994)......................... 5

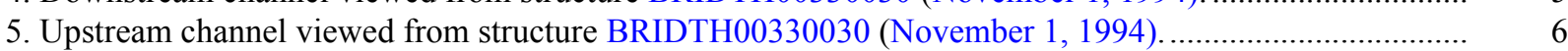

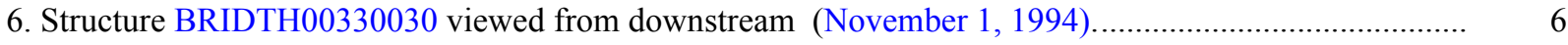

7. Water-surface profiles for the 100- and 500-year discharges at structure BRIDTH00330030 on Town Highway 33, crossing Dailey Hollow Branch, Bridgewater, Vermont.

8. Scour elevations for the 100-year discharge at structure BRIDTH00330030 on

Town Highway 33, crossing Dailey Hollow Branch, Bridgewater, Vermont. 3

5

(5)

6

6




\begin{tabular}{|c|c|c|}
\hline Multiply & By & To obtain \\
\hline \multicolumn{3}{|c|}{ Length } \\
\hline inch (in.) & 25.4 & millimeter (mm) \\
\hline foot $(\mathrm{ft})$ & 0.3048 & meter $(\mathrm{m})$ \\
\hline mile (mi) & 1.609 & kilometer (km) \\
\hline \multicolumn{3}{|c|}{ Slope } \\
\hline foot per mile ( $\mathrm{ft} / \mathrm{mi})$ & 0.1894 & meter per kilometer $(\mathrm{m} / \mathrm{km})$ \\
\hline \multicolumn{3}{|c|}{ Area } \\
\hline square mile $\left(\mathrm{mi}^{2}\right)$ & 2.590 & square kilometer $\left(\mathrm{km}^{2}\right)$ \\
\hline \multicolumn{3}{|c|}{ Volume } \\
\hline cubic foot $\left(\mathrm{ft}^{3}\right)$ & $\begin{array}{l}0.02832 \\
\text { Velocity and Flow }\end{array}$ & cubic meter $\left(\mathrm{m}^{3}\right)$ \\
\hline foot per second (ft/s) & 0.3048 & meter per second $(\mathrm{m} / \mathrm{s})$ \\
\hline cubic foot per second $\left(\mathrm{ft}^{3} / \mathrm{s}\right)$ & 0.02832 & cubic meter per second $\left(\mathrm{m}^{3} / \mathrm{s}\right)$ \\
\hline $\begin{array}{l}\text { cubic foot per second per } \\
\text { square mile } \\
{\left[\left(\mathrm{ft}^{3} / \mathrm{s}\right) / \mathrm{mi}^{2}\right]}\end{array}$ & 0.01093 & $\begin{array}{l}\text { cubic meter per } \\
\text { second per square } \\
\text { kilometer }\left[\left(\mathrm{m}^{3} / \mathrm{s}\right) / \mathrm{km}^{2}\right]\end{array}$ \\
\hline
\end{tabular}

OTHER ABBREVIATIONS

$\begin{array}{lrlr}\mathrm{BF} & \text { bank full } & \text { LWW } & \text { left wingwall } \\ \mathrm{cfs} & \text { cubic feet per second } & \text { MC } & \text { main channel } \\ \mathrm{D}_{50} & \text { median diameter of bed material } & \text { RAB } & \text { right abutment } \\ \mathrm{DS} & \text { downstream } & \text { RABUT } & \text { face of right abutment } \\ \mathrm{elev} & \text { elevation } & \text { RB } & \text { right bank } \\ \mathrm{f} / \mathrm{p} & \text { flood plain } & \text { ROB } & \text { right overbank } \\ \mathrm{ft} & \text { square feet } & \text { RWW } & \text { right wingwall } \\ \mathrm{ft} / \mathrm{ft} & \text { feet per foot } & \text { TH } & \text { town highway } \\ \mathrm{JCT} & \text { junction } & \text { UB } & \text { under bridge } \\ \mathrm{LAB} & \text { left abutment } & \text { US } & \text { upstream } \\ \mathrm{LABUT} & \text { face of left abutment } & \text { USGS } & \text { United States Geological Survey } \\ \text { LB } & \text { left bank } & \text { VTAOT Vermont Agency of Transportation } \\ \text { LOB } & \text { left overbank } & \text { WSPRO } & \text { water-surface profile model }\end{array}$

In this report, the words "right" and "left" refer to directions that would be reported by an observer facing downstream. Sea level: In this report, "sea level" refers to the National Geodetic Vertical Datum of 1929-- a geodetic datum derived from a general adjustment of the first-order level nets of the United States and Canada, formerly called Sea Level Datum of 1929.

In the appendices, the above abbreviations may be combined. For example, USLB would represent upstream left bank. 


\title{
LEVEL II SCOUR ANALYSIS FOR BRIDGE 30 (BRIDTH00330030) ON TOWN HIGHWAY 33, CROSSING DAILEY HOLLOW BRANCH, BRIDGEWATER, VERMONT
}

\author{
By Scott A. Olson and Donald L. Song
}

\section{INTRODUCTION AND SUMMARY OF RESULTS}

This report provides the results of a detailed Level II analysis of scour potential at structure BRIDTH00330030 on town highway 33 crossing Dailey Hollow Branch, Bridgewater, Vermont (figures 1-8). A Level II study is a basic engineering analysis of the site, including a quantitative analysis of stream stability and scour (U.S. Department of Transportation, 1993). A Level I study is included in Appendix E of this report. A Level I study provides a qualitative geomorphic characterization of the study site. Information on the bridge available from VTAOT files was compiled prior to conducting Level I and Level II analyses and can be found in Appendix D.

The site is in the Green Mountain physiographic province of central Vermont in the town of Bridgewater. The 7.51- $\mathrm{mi}^{2}$ drainage area is in a predominantly rural and forested basin. In the vicinity of the study site, the surface cover is forest.

In the study area, Dailey Hollow Branch has an incised, sinuous channel with a slope of approximately $0.013 \mathrm{ft} / \mathrm{ft}$, an average channel top width of $45 \mathrm{ft}$ and an average channel depth of $5 \mathrm{ft}$. The channel bed material ranges from sand to boulder with a median grain size $\left(\mathrm{D}_{50}\right)$ of $60.7 \mathrm{~mm}(0.199 \mathrm{ft})$. The geomorphic assessment at the time of the Level I and Level II site visit on November 1, 1994, indicated that the reach was stable.

The town highway 33 crossing of Dailey Hollow Branch is a 31-ft-long, one-lane bridge consisting of one 25-foot steel-beam span with a timber deck (Vermont Agency of Transportation, written communication, August 25, 1994). The bridge is supported by vertical, concrete abutments with wingwalls. The channel is skewed approximately 20 degrees to the opening while the opening-skew-to-roadway is 0 degrees. Type- 2 stone-fill (less than 36 inches diameter) protection was found at all four wingwalls. Additional details describing conditions at the site are included in the Level II Summary and Appendices D and $\mathrm{E}$. 
Scour depths and rock rip-rap sizes were computed using the general guidelines described in Hydraulic Engineering Circular 18 (Richardson and others, 1993). Total scour at a highway crossing is comprised of three components: 1) long-term streambed degradation; 2) contraction scour (due to accelerated flow caused by a reduction in flow area at a bridge) and; 3) local scour (caused by accelerated flow around piers and abutments). Total scour is the sum of the three components. Equations are available to compute depths for contraction and local scour and a summary of the results of these computations follows.

Contraction scour for all modelled flows ranged from 0.5 to $3.1 \mathrm{ft}$. The worst-case contraction scour occurred at the incipient-roadway-overtopping discharge, which is between the 100- and 500-year discharge. Abutment scour ranged from 6.9 to $14.6 \mathrm{ft}$. with the worst-case scenario also occurring at the incipient-roadway-overtopping discharge. Additional information on scour depths and depths to armoring are included in the section titled "Scour Results". Scoured-streambed elevations, based on the calculated scour depths, are presented in tables 1 and 2. A cross-section of the scour computed at the bridge is presented in figure 8 . Scour depths were calculated assuming an infinite depth of erosive material and a homogeneous particle-size distribution.

It is generally accepted that the Froehlich equation (abutment scour) gives "excessively conservative estimates of scour depths" (Richardson and others, 1993, p. 48). Many factors, including historical performance during flood events, the geomorphic assessment, scour protection measures, and the results of the hydraulic analyses, must be considered to properly assess the validity of abutment scour results. Therefore, scour depths adopted by VTAOT may differ from the computed values documented herein, based on the consideration of additional contributing factors and experienced engineering judgement. 


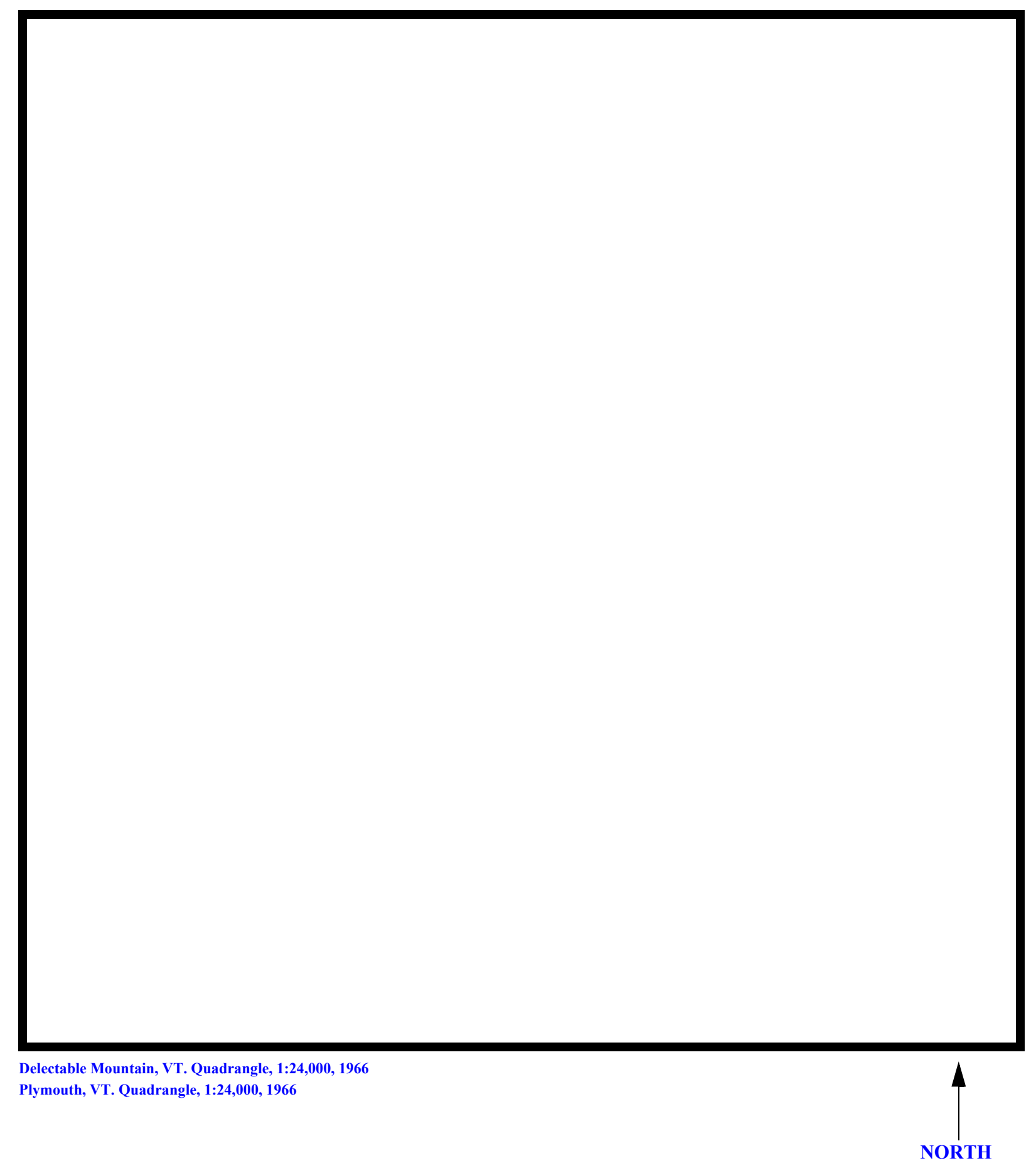

Figure 1. Location of study area on USGS 1:24,000 scale map. 
Figure 2. Location of study area on Vermont Agency of Transportation town highway map. 

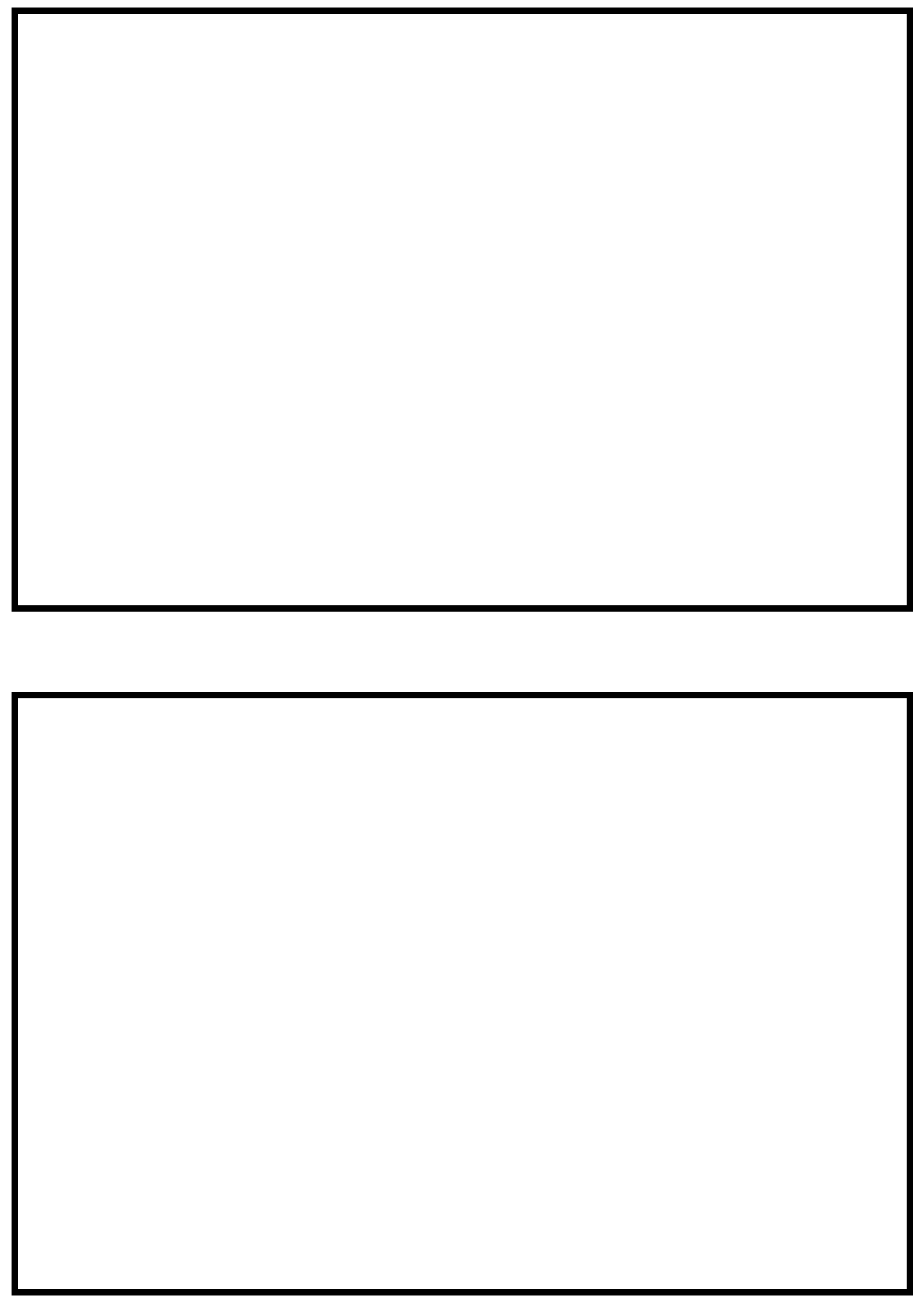

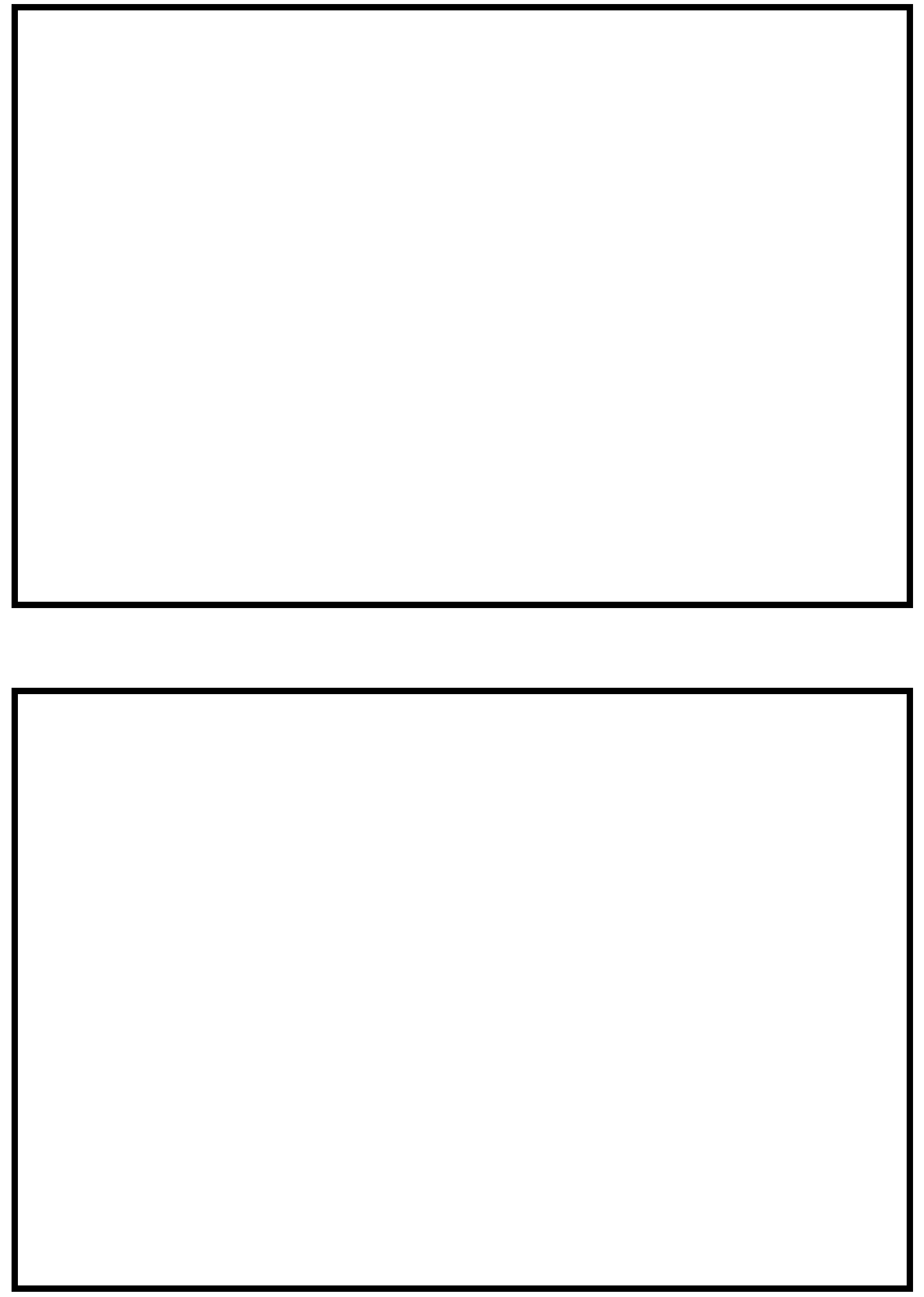


\section{LEVEL II SUMMARY}

\begin{tabular}{llllll} 
& Structure Number & BRIDTH00330030 & & \multicolumn{2}{c}{ Dailey Hollow Branch } \\
Stream & & & & \\
County & Windsor & Road & TH0033 & District & 4
\end{tabular}

\section{Description of Bridge}

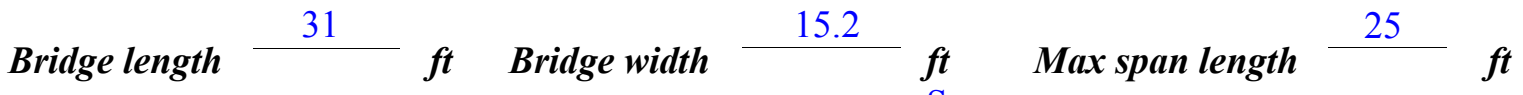
Alignment of bridge to road (on curve or straight) vertical, concrete Abutment type

Stone fill on abutment? no

\section{Embankment type} S-curve sloping downstream right wingwall was noted as being in good condition.

Abutments are vertical and concrete. The top of the

footing of the left abutment is exposed.

\section{Y}

Is bridge skewed to flood flow according to Y ' survey?

Angle

Mild bend with left abutment being impacted at about 20.degrees to the face of the abutment. $11 / 1 / 94$

Debris accumulation on bridge at time of Level I or Level II site visit:

\begin{tabular}{|c|c|c|c|}
\hline & $\begin{array}{l}\text { Date of insnortion } \\
0\end{array}$ & $\begin{array}{l}\text { Percent of nlommal } \\
\text { blocked inortzontatly }\end{array}$ & $\begin{array}{l}\text { Percent o } 11 / 1 / \\
\text { blocked verticatty }\end{array}$ \\
\hline el I & 94 & 0 & 0 \\
\hline Level II & Moderate, & the stream is in a fores & ley. \\
\hline
\end{tabular}

\section{Potential for debris}

November 1, 1994--None.

Dosriho anv, fonturos noar ar at tho hridoo that mav affort flow, (includo ahsorvation dato) 


\section{Description of the Geomorphic Setting}

General topography The bridge crosses a high gradient incised upland stream with terraces in a moderate relief valley.

Geomorphic conditions at bridge site: downstream (DS), upstream (US)

Date of inspection $\quad 11 / 1 / 94$

DS left: $\quad$ High narrow terrace to valley wall.

DS right: $\quad$ High narrow terrace to valley wall.

US left: $\quad$ High narrow terrace to valley wall.

US right: $\quad$ Steep valley wall with gravel road parallel to channel.

\section{Description of the Channel}

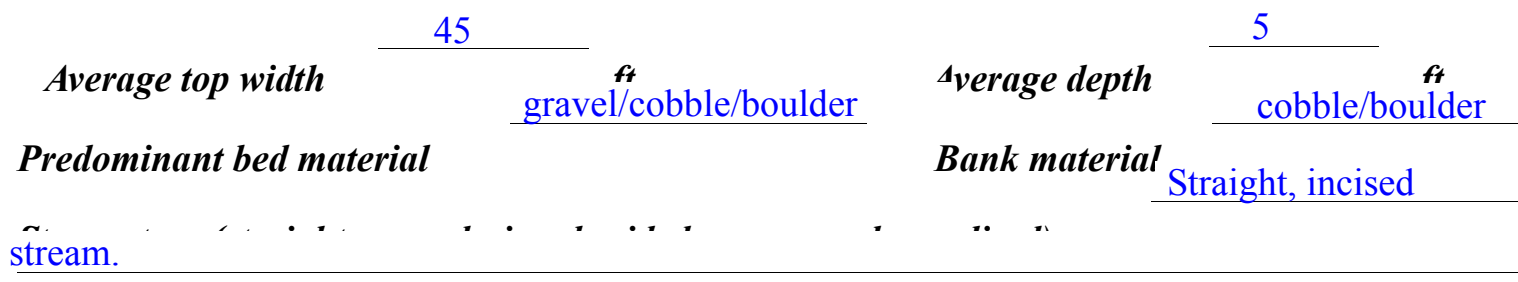

Vegetative co $^{1}$ Forest with gravel road paralleil to chännel bäk.

$11 / 1 / 94$

DS left: $\quad$ Forest.

DS right: $\quad$ Forest.

US left: $\quad$ Forest with gravel road parallel to channel bank.

US right: $\quad \underline{\mathrm{Y}}$

Do banks appear stable? 11/1/94

date of observatton.

November 1, 1994--

None.

Describe any obstructions in channel and date of observation. 


\title{
Hydrology
}

Drainage area $\stackrel{7.51}{\longrightarrow} \mathbf{m i}^{2}$

Percentage of drainage area in physiographic provinces: (approximate)

Physiographic province

Green Mountain
Percent of drainage area 100

\begin{abstract}
Is drainage area considered rural or urban?
Rural urbanization: None.

Describe any significant
\end{abstract}

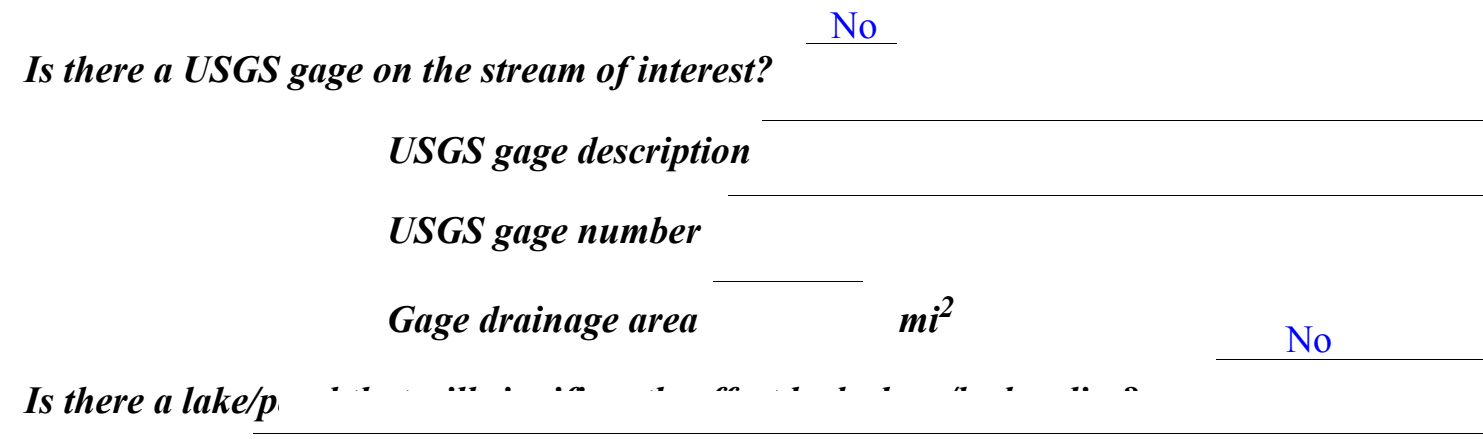

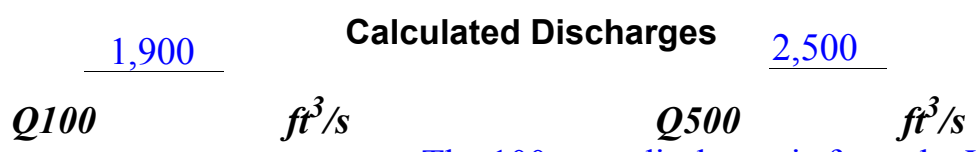

The 100-year discharge is from the VTAOT

database (VTAOT, written communication, May 1995). The 500-year discharge was selected from a range determined by several empirical methods (Potter, 1957a\&b; Johnson and Tasker, 1974; FHWA, 1983; Talbot, 1887; Richardson and others, 1993). 


\section{Description of the Water-Surface Profile Model (WSPRO) Analysis}

Datum for WSPRO analysis (USGS survey, sea level, VTAOT plans)

USGS survey

Datum tie between USGS survey and VTAOT plans

Subtract $1 \mathrm{ft}$ from USGS survey

datum to obtain VTAOT plan's datum.

Description of reference marks used to determine USGS datum. $\quad$ RM1 is a chiseled X on

top of the upstream end of the right abutment (elev. $499.62 \mathrm{ft}$, arbitrary survey datum). RM2 is a

chiseled X on top of the downstream end of the left abutment (elev. $499.46 \mathrm{ft}$, arbitrary survey

datum).

\section{Cross-Sections Used in WSPRO Analysis}

\begin{tabular}{cccl}
\hline${ }^{1}$ Cross-section & $\begin{array}{c}\text { Section } \\
\text { Reference } \\
\text { Distance } \\
\text { (SRD) } \text { in feet }\end{array}$ & $\begin{array}{c}\text { 2 Cross-section } \\
\text { development }\end{array}$ & \multicolumn{1}{c}{ Comments } \\
\hline EXIT1 & -43 & 1 & $\begin{array}{l}\text { Exit section } \\
\text { Downstream Full-valley } \\
\text { section (Templated from } \\
\text { EXITX) }\end{array}$ \\
FULLV & 0 & 2 & $\begin{array}{l}\text { Bridge section } \\
\text { RRIDG }\end{array}$ \\
RDWAY & 0 & 1 & $\begin{array}{l}\text { Road Grade section } \\
\text { Modelled Approach sec- } \\
\text { tion (Templated from } \\
\text { APTEM) } \\
\text { APPRO }\end{array}$ \\
APTEM & 50 & 1 & $\begin{array}{l}\text { Approach section as sur- } \\
\text { veyed (Used as a tem- } \\
\text { plate) }\end{array}$ \\
\hline
\end{tabular}

${ }^{1}$ For location of cross-sections see plan-view sketch included with Level I field form, Appendix E.

For more detail on how cross-sections were developed see WSPRO input file. 


\section{Data and Assumptions Used in WSPRO Model}

Hydraulic analyses of the reach were done by use of the Federal Highway Administration's WSPRO step-backwater computer program (Shearman and others, 1986, and Shearman, 1990). The analysis reported herein reflects conditions existing at the site at the time of the study. Furthermore, in the development of the model it was necessary to assume no accumulation of debris or ice at the site. Results of the hydraulic model are presented in the Bridge Hydraulic Summary, Appendix B, and figure 7.

Channel roughness factors (Manning's " $n$ ") used in the hydraulic model were estimated using field inspections at each cross section following the general guidelines described by Arcement, Jr. and Schneider (1989). Final adjustments to the values were made during the modelling of the reach. Channel " $\mathrm{n}$ " values for the reach ranged from 0.055 to 0.060 , and overbank " $\mathrm{n}$ " values ranged from 0.035 to 0.100 .

Normal depth at the exit section (EXIT1) was assumed as the starting water surface. This depth was computed by use of the slope-conveyance method outlined in the User's manual for WSPRO (Shearman, 1990). The slope used was $0.013 \mathrm{ft} / \mathrm{ft}$ which was determined from an analysis of surveyed thalweg and water surface points downstream of the bridge and the topographic map (U.S. Geological Survey, 1966).

The surveyed approach section (APTEM) was moved along the approach channel slope $(0.010 \mathrm{ft} / \mathrm{ft})$ to establish the modelled approach section (APPRO), one bridge length upstream of the upstream face as recommended by Shearman and others (1986). This approach also provides a consistent method for determining scour variables.

For the 100-year and incipient overtopping discharge, WSPRO assumes critical depth at the bridge section. Supercritical models were developed for these discharges. Analyzing both the supercritical and subcritical profiles for each discharge, it can be determined that the water surface profile does pass through critical depth within the bridge opening. Thus, the assumptions of critical depth at the bridge are satifactory solutions. 


\section{Bridge Hydraulics Summary}

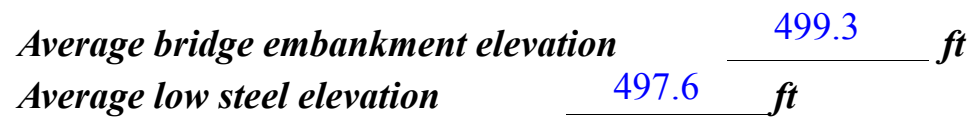

$$
\text { 100-year discharge } \quad 1,900 \quad \mathrm{ft}^{3} / \mathrm{s}
$$

Water-surface elevation in bridge opening

Road overtopping? ___ N Discharge over road $492.9 \boldsymbol{f t}$

\begin{tabular}{lccc} 
Area of flow in bridge opening & $138 \quad \boldsymbol{f t}^{2}$ \\
\cline { 2 - 3 } Average velocity in bridge opening & $13.8 \quad \boldsymbol{f t} / \mathbf{s}$
\end{tabular}

$\begin{array}{llll}\text { Maximum WSPRO tube velocity at bridge } & 17.0 \mathrm{ft} / \mathrm{s}\end{array}$

Water-surface elevation at Approach section with bridge 496.7

Water-surface elevation at Approach section without bridge $\quad \overline{493.9}$

Amount of backwater caused by bridge $\quad 2.8$ it

500-year discharge $\quad 2,500 \quad \mathrm{ft}^{3} / \mathrm{s}$

Water-surface elevation in bridge opening $\quad 497.6 \mathrm{ft}$

Road overtopping? ___ Y Discharge over road__ $185, \% / s$

Area of flow in bridge opening _ $\quad 246 \quad \mathrm{ft}^{2}$

Average velocity in bridge opening $\quad 9.5 \mathrm{ft} / \mathrm{s}$

Maximum WSPRO tube velocity at bridge 11.5 /s

Water-surface elevation at Approach section with bridge 499.6

Water-surface elevation at Approach section without bridge $\quad 494.5$

Amount of backwater caused by bridge 5.1 .

Incipient overtopping discharge $\quad 2,310 \mathrm{ft}^{3} / \mathrm{s}$

Water-surface elevation in bridge opening $493.7 \quad t$

\begin{tabular}{lrr} 
Area of flow in bridge opening & $157 \quad \boldsymbol{f t}^{\mathbf{2}}$ \\
\cline { 2 - 2 } Average velocity in bridge opening & 14.7
\end{tabular}

Average velocity in bridge opening $\quad 14.7 \quad \mathrm{ft} / \mathrm{s}$

Maximum WSPRO tube velocity at bridge $\quad 18.4 \mathrm{ft} / \mathrm{s}$

Water-surface elevation at Approach section with bridge

Water-surface elevation at Approach section without bridge

497.9

Amount of backwater caused by bridge $\quad 3.6$, $t$ 


\section{Scour Analysis Summary}

\section{Special Conditions or Assumptions Made in Scour Analysis}

Scour depths were computed using the general guidelines described in Hydraulic Engineering Circular 18 (Richardson and others, 1993). Scour depths were calculated assuming an infinite depth of erosive material and a homogeneous particle-size distribution. The results of the scour analysis are presented in tables 1 and 2 and a graph of the scour depths is presented in figure 8 .

Contraction scour was computed by use of the clear-water contraction scour equation (Richardson and others, 1993, p. 35, equation 18) for the 100-year and incipient overtopping discharges. Contraction scour was computed by use of Chang pressure-flow scour equation (Richardson and others, 1995, p. 145-146) for the 500-year discharge, where orifice flow occurred at the bridge. Contraction scour at bridges with orifice flow is best estimated by use of the Chang pressure-flow scour equation (oral communication, J. Sterling Jones, October 4, 1996). The results of Laursen's clear-water contraction scour equation (Richardson and others, 1993, p. 35, equation 18) for the 500-year discharge was also computed and can be found in appendix F. For contraction scour computations using the Laursen's equation, the average depth in the contracted section (AREA/TOPWIDTH) is subtracted from the depth of flow computed by the scour equation (Y2) to determine the actual amount of scour.

Abutment scour was computed by use of the Froehlich equation (Richardson and others, 1993, p. 49, equation 24). Variables for the Froehlich equation include the Froude number of the flow approaching the embankments, the length of the embankment blocking flow, and the depth of flow approaching the embankment less any roadway overtopping.

The incipient overtopping discharge resulted in the worst case contraction scour results. This discharge also resulted in worst case total scour. Also, the 100-year scour depths were greater than the 500 -year scour depths. Thus, figure 8 only shows the 100 -year scour depths. 


\section{Scour Results}

$$
\text { 100-yr discharge 500-yr discharge }
$$

Contraction scour:

Main channel

Live-bed scour

Clear-water scour

Depth to armoring

Left overbank

Right overbank

Local scour:

Abutment scour

Left abutment

Right abutment

Pier scour

Pier 1

Pier 2

Pier 3
(Scour depths in feet)
Incipient
chtopping
charge

(Scour depths infeet) 


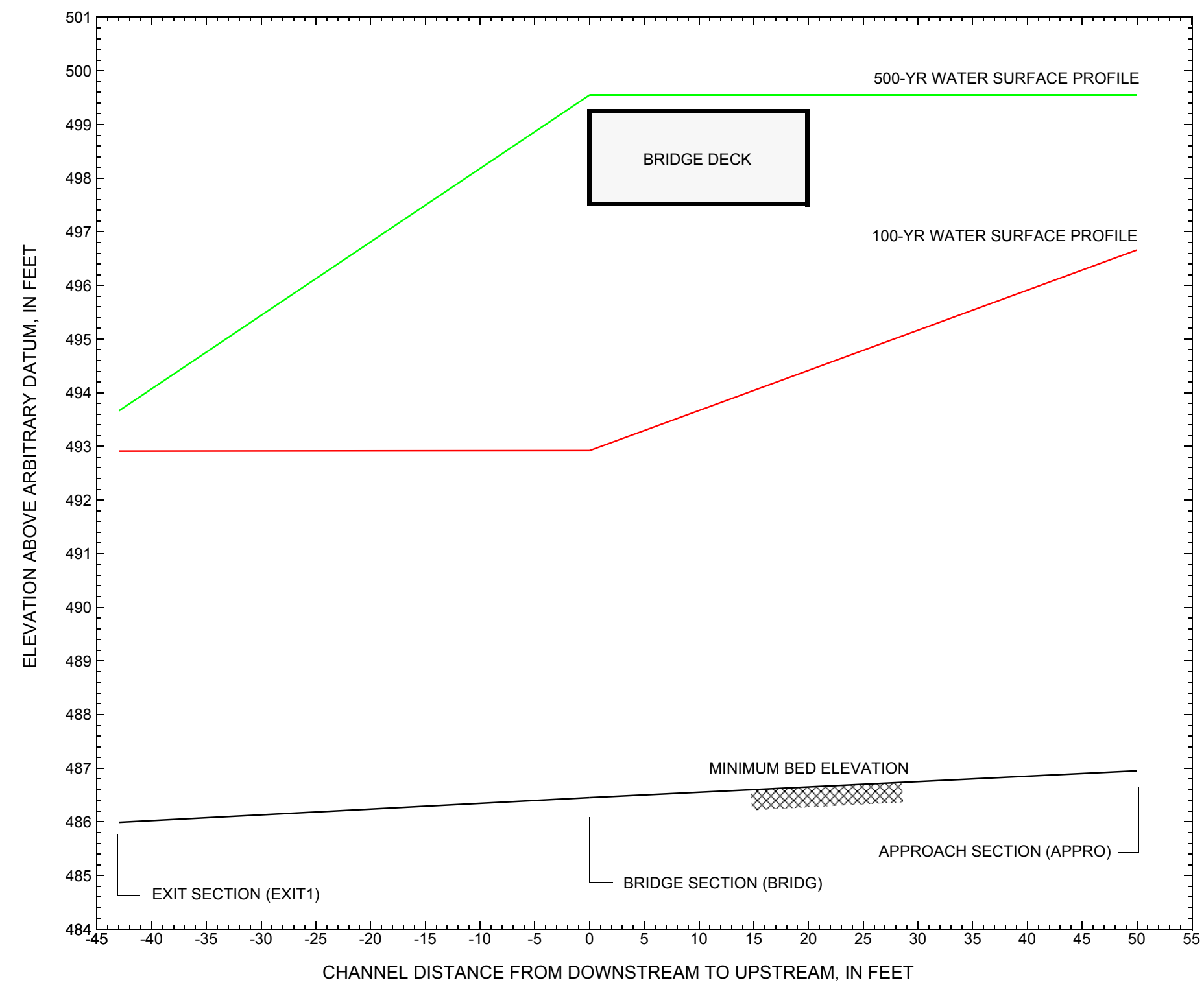

Figure 7. Water-surface profiles for the 100- and 500-yr discharges at structure BRIDTH00330030 on town highway 33, crossing Dailey Hollow Branch, Bridgewater, Vermont. 


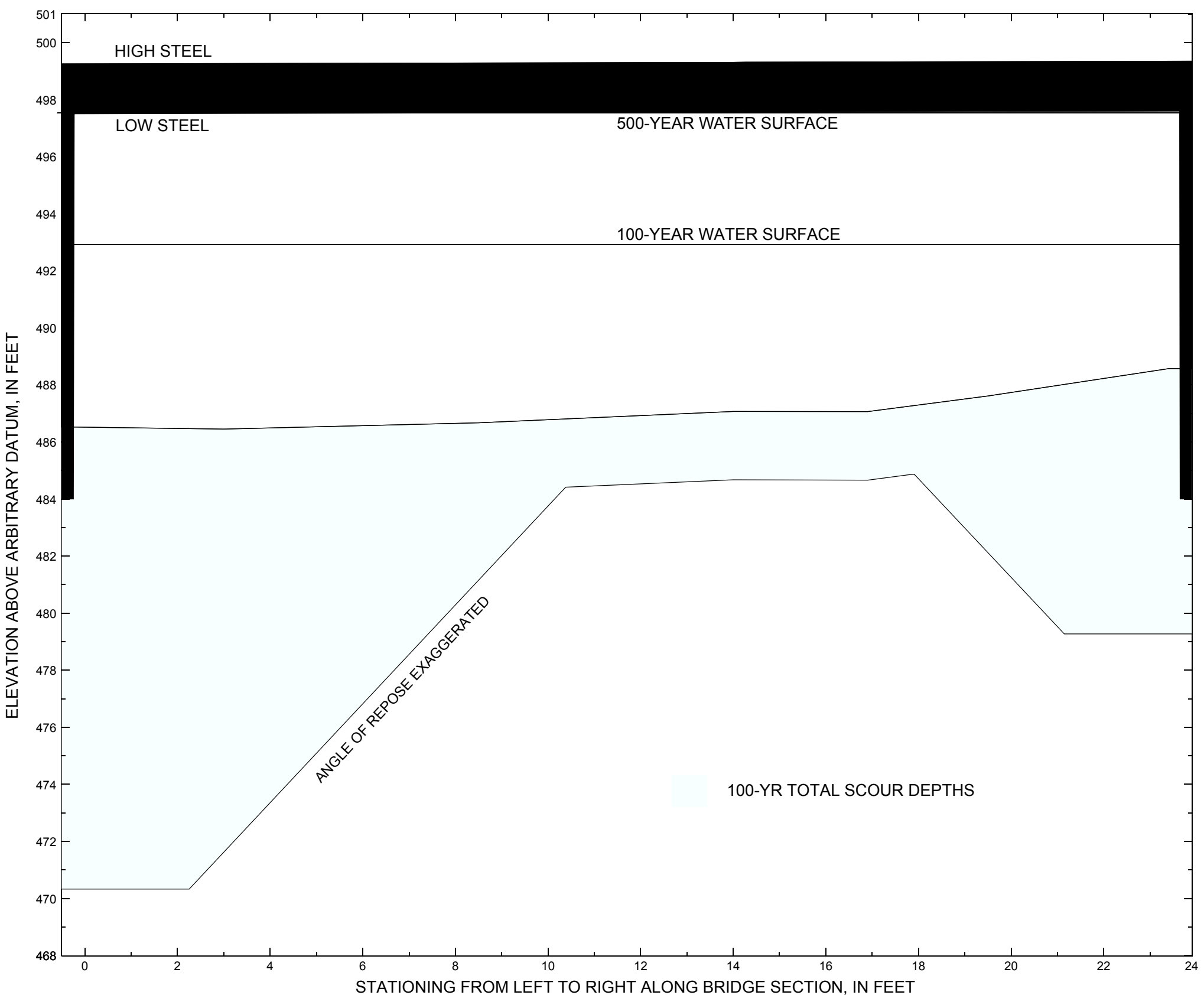

Figure 8. Scour elevations for the 100-year discharge at structure BRIDTH00330030 on town highway 33, crossing Dailey Hollow Branch, Bridgewater, Vermont. 
Table 1. Remaining footing/pile depth at abutments for the 100-year discharge at structure BRIDTH00330030 on Town Highway 33, crossing Dailey Hollow Branch, Bridgewater, Vermont.

[VTAOT, Vermont Agency of Transportation; --,no data]

\begin{tabular}{|c|c|c|c|c|c|c|c|c|c|c|c|}
\hline Description & Station $^{1}$ & $\begin{array}{c}\text { VTAOT } \\
\text { plans' } \\
\text { bridge seat } \\
\text { elevation } \\
\text { (feet) }\end{array}$ & $\begin{array}{l}\text { Surveyed } \\
\text { minimum } \\
\text { low-chord } \\
\text { elevation } \\
\quad \text { (feet) }\end{array}$ & $\begin{array}{l}\text { Bottom of } \\
\text { footing } \\
\text { elevation } \\
\text { (feet) }\end{array}$ & $\begin{array}{c}\text { Channel } \\
\text { elevation at } \\
\text { abutment/ } \\
\text { pier }^{2} \\
\text { (feet) }\end{array}$ & $\begin{array}{l}\text { Contraction } \\
\text { scour depth } \\
\text { (feet) }\end{array}$ & $\begin{array}{l}\text { Abutment } \\
\text { scour } \\
\text { depth } \\
\text { (feet) }\end{array}$ & $\begin{array}{l}\text { Pier } \\
\text { scour } \\
\text { depth } \\
\text { (feet) }\end{array}$ & $\begin{array}{l}\text { Depth of } \\
\text { total scour } \\
\text { (feet) }\end{array}$ & $\begin{array}{c}\text { Elevation of } \\
\text { scour }^{2} \\
\text { (feet) }\end{array}$ & $\begin{array}{c}\text { Remaining } \\
\text { footing/pile } \\
\text { depth } \\
\text { (feet) }\end{array}$ \\
\hline \multicolumn{12}{|c|}{100 -yr. discharge is 1,900 cubic-feet per second } \\
\hline Left abutment & 0.0 & 496.6 & 497.5 & 484 & 486.5 & 2.4 & 13.8 & -- & 16.2 & 470.3 & -14 \\
\hline Right abutment & 23.4 & 496.9 & 497.6 & 484 & 488.6 & 2.4 & 6.9 & -- & 9.3 & 479.3 & -5 \\
\hline
\end{tabular}

1. Measured along the face of the most constricting side of the bridge.

2. Arbitrary datum for this study.

Table 2. Remaining footing/pile depth at abutments for the 500-year discharge at structure BRIDTH00330030 on Town Highway 33, crossing Dailey Hollow Branch, Bridgewater, Vermont.

[VTAOT, Vermont Agency of Transportation; --, no data]

\begin{tabular}{|c|c|c|c|c|c|c|c|c|c|c|c|}
\hline Description & Station $^{1}$ & $\begin{array}{c}\text { VTAOT } \\
\text { plans' } \\
\text { bridge seat } \\
\text { elevation } \\
\text { (feet) }\end{array}$ & $\begin{array}{c}\text { Surveyed } \\
\text { minimum } \\
\text { low-chord } \\
\text { elevation }{ }^{2} \\
\text { (feet) }\end{array}$ & $\begin{array}{c}\text { Bottom of } \\
\text { footing } \\
\text { elevation } \\
\text { (feet) }\end{array}$ & $\begin{array}{c}\text { Channel } \\
\text { elevation at } \\
\text { abutment/ } \\
\text { pier }^{2} \\
\text { (feet) }\end{array}$ & $\begin{array}{l}\text { Contraction } \\
\text { scour depth } \\
\text { (feet) }\end{array}$ & $\begin{array}{l}\text { Abutment } \\
\text { scour } \\
\text { depth } \\
\text { (feet) }\end{array}$ & $\begin{array}{l}\text { Pier } \\
\text { scour } \\
\text { depth } \\
\text { (feet) }\end{array}$ & $\begin{array}{l}\text { Depth of } \\
\text { total scour } \\
\text { (feet) }\end{array}$ & $\begin{array}{c}\text { Elevation of } \\
\text { scour }^{2} \\
\text { (feet) }\end{array}$ & $\begin{array}{c}\text { Remaining } \\
\text { footing/pile } \\
\text { depth } \\
\text { (feet) }\end{array}$ \\
\hline \multicolumn{12}{|c|}{500 -yr. discharge is 2,500 cubic-feet per second } \\
\hline Left abutment & 0.0 & 496.6 & 497.5 & 484 & 486.5 & 0.5 & 14.5 & -- & 15.0 & 471.5 & -13 \\
\hline Right abutment & 23.4 & 496.9 & 497.6 & 484 & 488.6 & 0.5 & 7.1 & -- & 7.6 & 481.0 & -3 \\
\hline
\end{tabular}

1. Measured along the face of the most constricting side of the bridge.

2. Arbitrary datum for this study. 


\section{SELECTED REFERENCES}

Arcement, G.J., Jr., and Schneider, V.R., 1989, Guide for selecting Manning's roughness coefficients for natural channels and flood plains: U.S. Geological Survey Water-Supply Paper 2339, 38 p.

Barnes, H.H., Jr., 1967, Roughness characteristics of natural channels: U.S. Geological Survey Water-Supply Paper 1849,213 p.

Brown, S.A. and Clyde, E.S., 1989, Design of riprap revetment: Federal Highway Administration Hydraulic Engineering Circular No. 11, Publication FHWA-IP-89-016, 156 p.

Federal Highway Administration, 1983, Runoff estimates for small watersheds and development of sound design: Federal Highway Administration Report FHWA-RD-77-158

Froehlich, D.C., 1989, Local scour at bridge abutments in Ports, M.A., ed., Hydraulic Engineering--Proceedings of the 1989 National Conference on Hydraulic Engineering: New York, American Society of Civil Engineers, p. 13-18.

Hayes, D.C.,1993, Site selection and collection of bridge-scour data in Delaware, Maryland, and Virginia: U.S. Geological Survey WaterResources Investigation Report 93-4017, 23 p.

Interagency Advisory Committee on Water Data, 1982, Guidelines for determining flood flow frequency: U.S. Geological Survey, Bulletin 17B of the Hydrology Subcommittee, 190 p.

Johnson, C.G. and Tasker, G.D.,1974, Progress report on flood magnitude and frequency of Vermont streams: U.S. Geological Survey OpenFile Report 74-130, 37 p.

Lagasse, P.F., Schall, J.D., Johnson, F., Richardson, E.V., Richardson, J.R., Chang, F., 1991, Stream Stability at Highway Structures: Federal Highway Administration Hydraulic Engineering Circular No. 20, Publication FHWA-IP-90-014, 195 p.

Laursen, E.M., 1960, Scour at bridge crossings: Journal of the Hydraulics Division, American Society of Civil Engineers, v. 86, no. HY2, p. 39-53.

Potter, W. D., 1957a, Peak rates of runoff in the Adirondack, White Mountains, and Maine woods area, Bureau of Public Roads

Potter, W. D., 1957b, Peak rates of runoff in the New England Hill and Lowland area, Bureau of Public Roads

Richardson, E.V., and Davis, S.R., 1995, Evaluating scour at bridges: Federal Highway Administration Hydraulic Engineering Circular No. 18, Publication FHWA-IP-90-017, 204 p.

Richardson, E.V., Harrison, L.J., Richardson, J.R., and Davis, S.R., 1993, Evaluating scour at bridges: Federal Highway Administration Hydraulic Engineering Circular No. 18, Publication FHWA-IP-90-017, 131 p.

Richardson, E.V., Simons, D.B., and Julien, P.Y., 1990, Highways in the river environment: Federal Highway Administration Publication FHWA-HI-90-016.

Ritter, D.F., 1984, Process Geomorphology: W.C. Brown Co., Debuque, Iowa, 603 p.

Shearman, J.O., 1990, User's manual for WSPRO--a computer model for water surface profile computations: Federal Highway Administration Publication FHWA-IP-89-027, 187 p.

Shearman, J.O., Kirby, W.H., Schneider, V.R., and Flippo, H.N., 1986, Bridge waterways analysis model; research report: Federal Highway Administration Publication FHWA-RD-86-108, 112 p.

Talbot, A.N., 1887, The determination of water-way for bridges and culverts.

U.S. Department of Transportation, 1993, Stream stability and scour at highway bridges, Participant Workbook: Federal Highway Administration Publication FHWA HI-91-011.

U.S. Geological Survey, 1966, Delectable Mountain, Vermont 7.5 Minute Series quadrangle map: U.S. Geological Survey Topographic Maps, Photoinspected 1983, Scale 1:24,000.

U.S. Geological Survey, 1966, Plymouth, Vermont 7.5 Minute Series quadrangle map: U.S. Geological Survey Topographic Maps, Photoinspected 1983, Scale 1:24,000. 


\section{APPENDIX A: \\ WSPRO INPUT FILE}




\section{WSPRO INPUT FILE}

GR

GR

GR

$\mathrm{N}$

SA

\section{*}

$\mathrm{X}$

*

BR

GR

GR

GR

$\mathrm{N}$

CD

*

XR

GR

GR

\section{*}

$\mathrm{XT}$

GR

GR

GR

GR

GR

*

AS APPRO 50

GT $\quad-0.19$

$\mathrm{N}$

SA

\section{*}

HP 1 BRIDG

HP 2 BRIDG

HP 1 APPRO

HP 2 APPRO

*

HP 1 BRIDG

HP 2 BRIDG

HP 2 RDWAY

$\mathrm{HP} 1 \mathrm{APPRO}$

HP 2 APPRO

EXIT1 - 43
U.S. GEOLOGICAL SURVEY WSPRO INPUT FILE brid030.wsp CREATED ON 21-SEP-95 FOR BRIDGE BRIDTH00330030 USING FILE brid030.dCa HYDRAULIC ANALYSIS OF BRID030 SAO

$\begin{array}{lllllllllllllllllllll}6 & 29 & 30 & 552 & 553 & 551 & 5 & 16 & 17 & 13 & 3 & * & 15 & 14 & 23 & 21 & 11 & 12 & 4 & 7 & 3\end{array}$

190025002310

$0.0130 .013 \quad 0.013$

$$
-67.1,508.33
$$

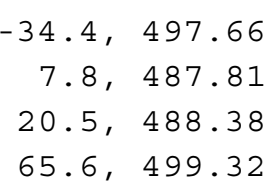

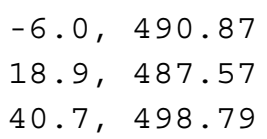




\section{APPENDIX B: \\ WSPRO OUTPUT FILE}


WSPRO OUTPUT FILE

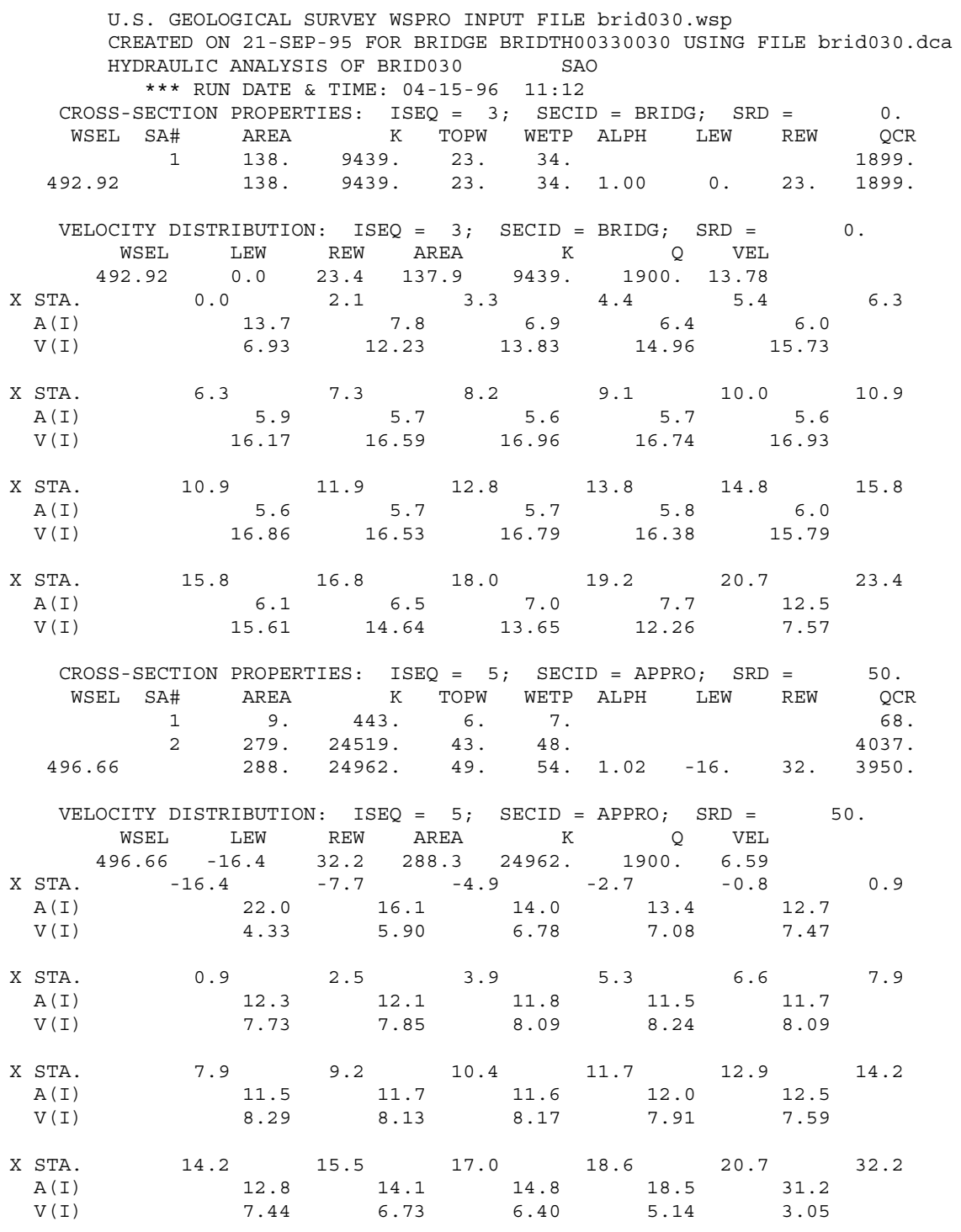


WSPRO OUTPUT FILE (continued)

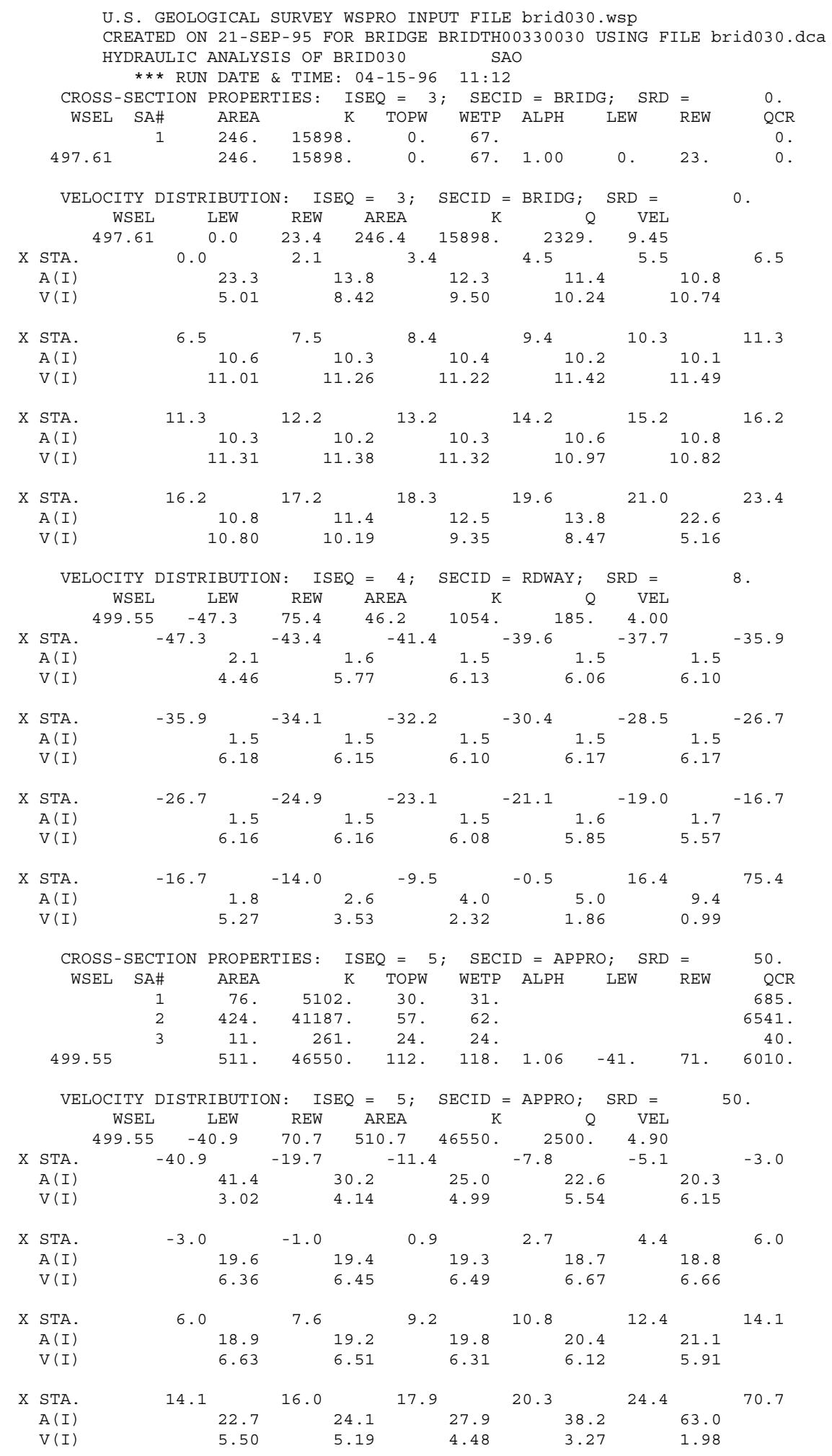


WSPRO OUTPUT FILE (continued)

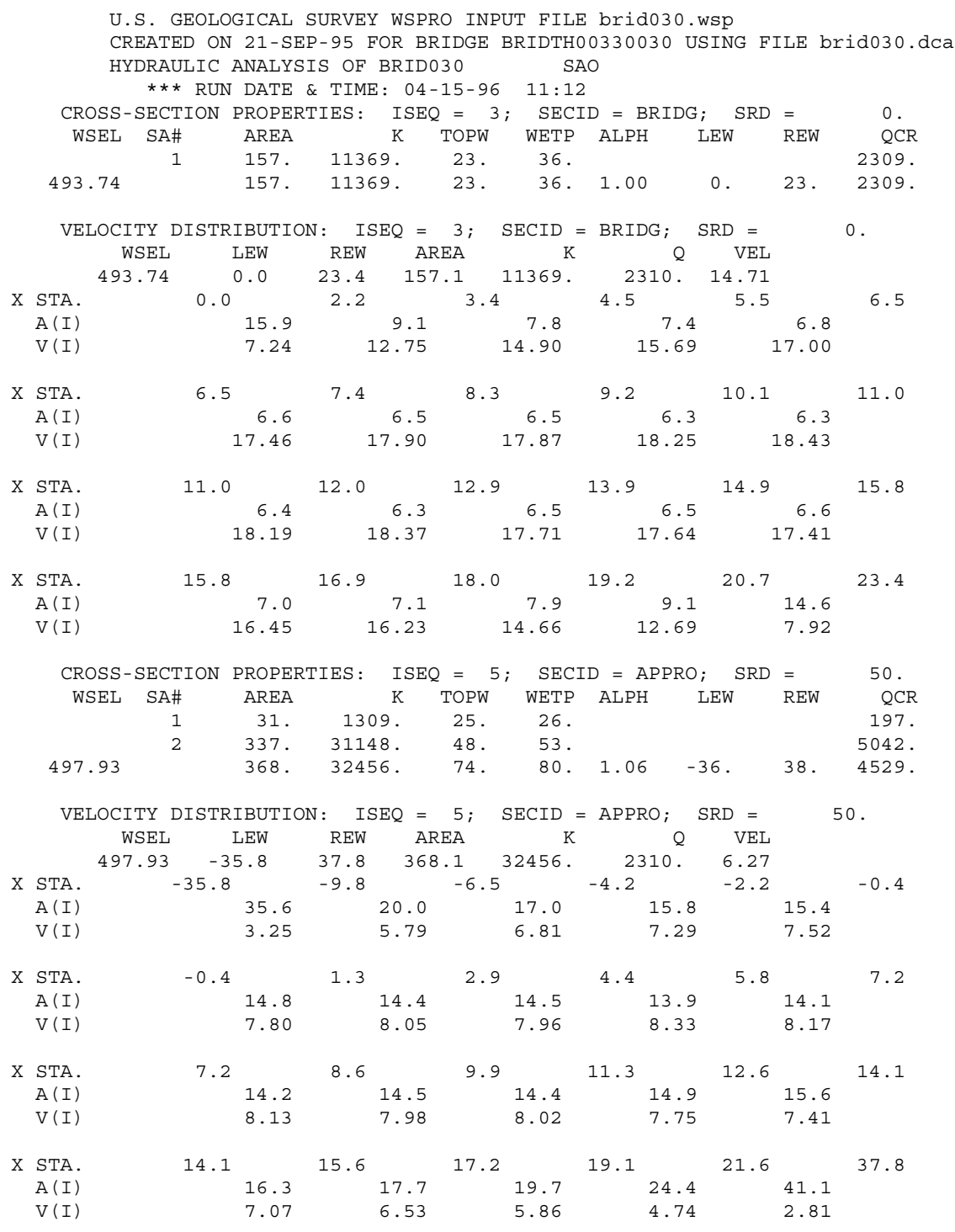


WSPRO OUTPUT FILE (continued)

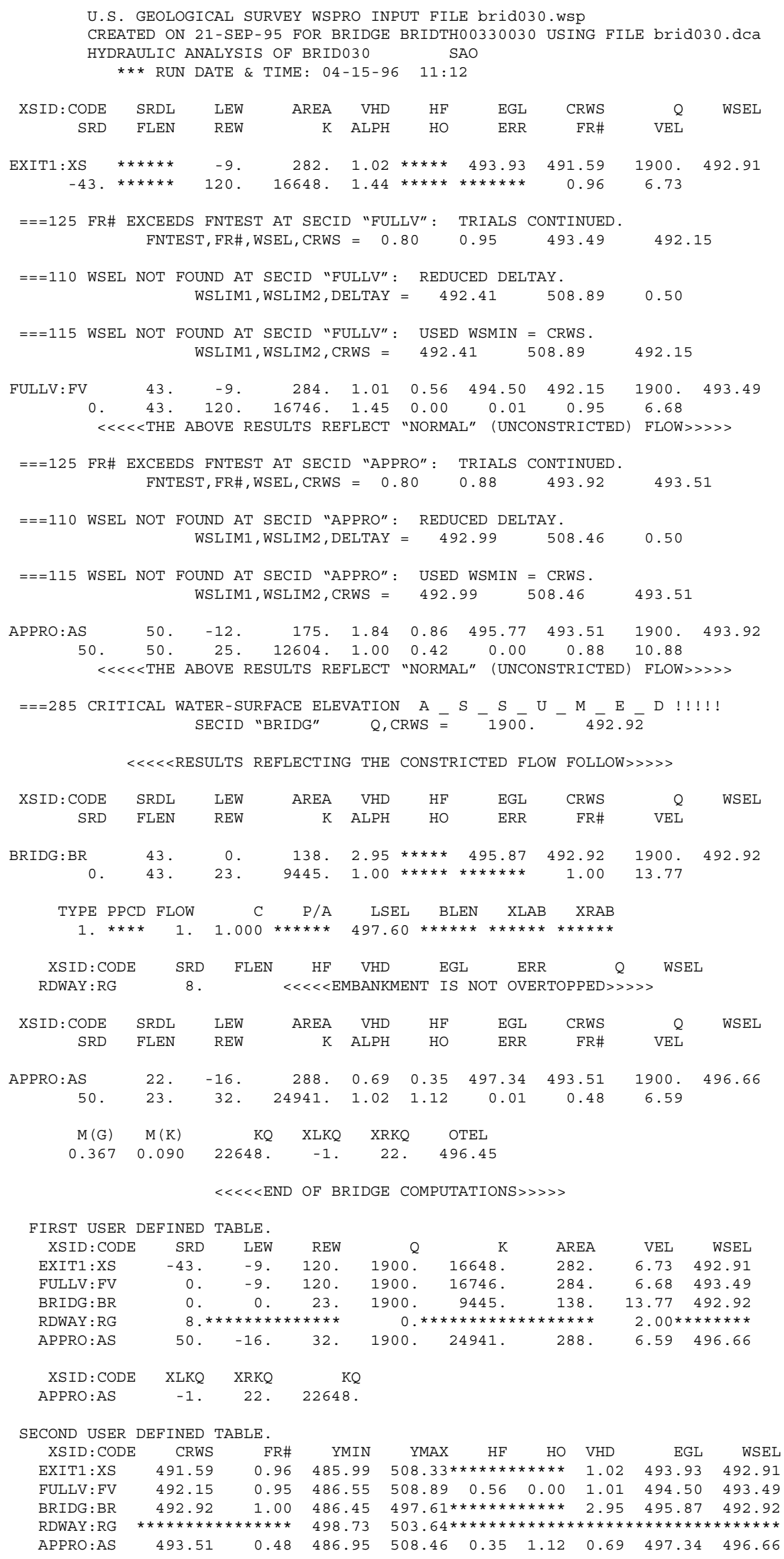


WSPRO OUTPUT FILE (continued)

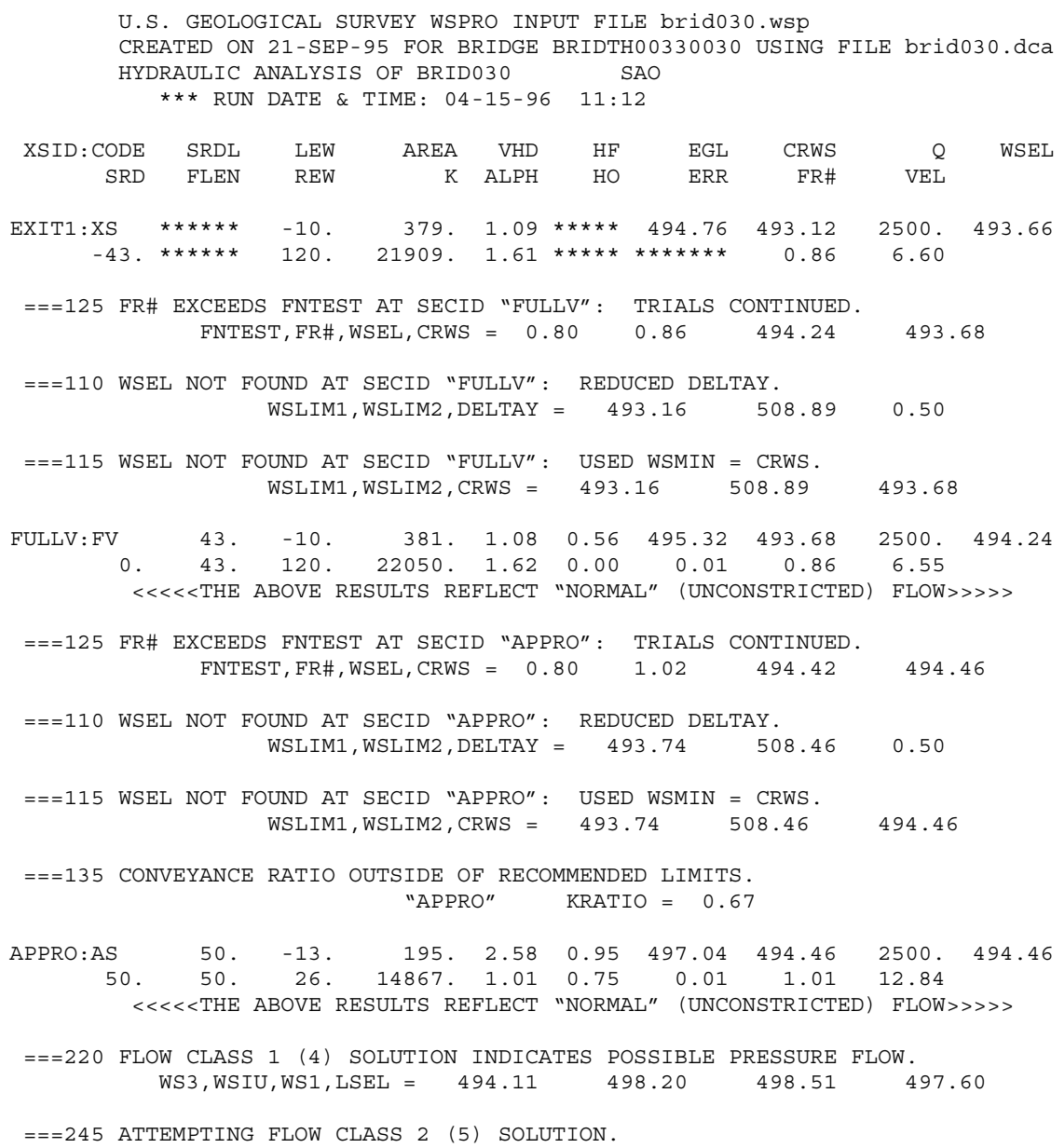


WSPRO OUTPUT FILE (continued)

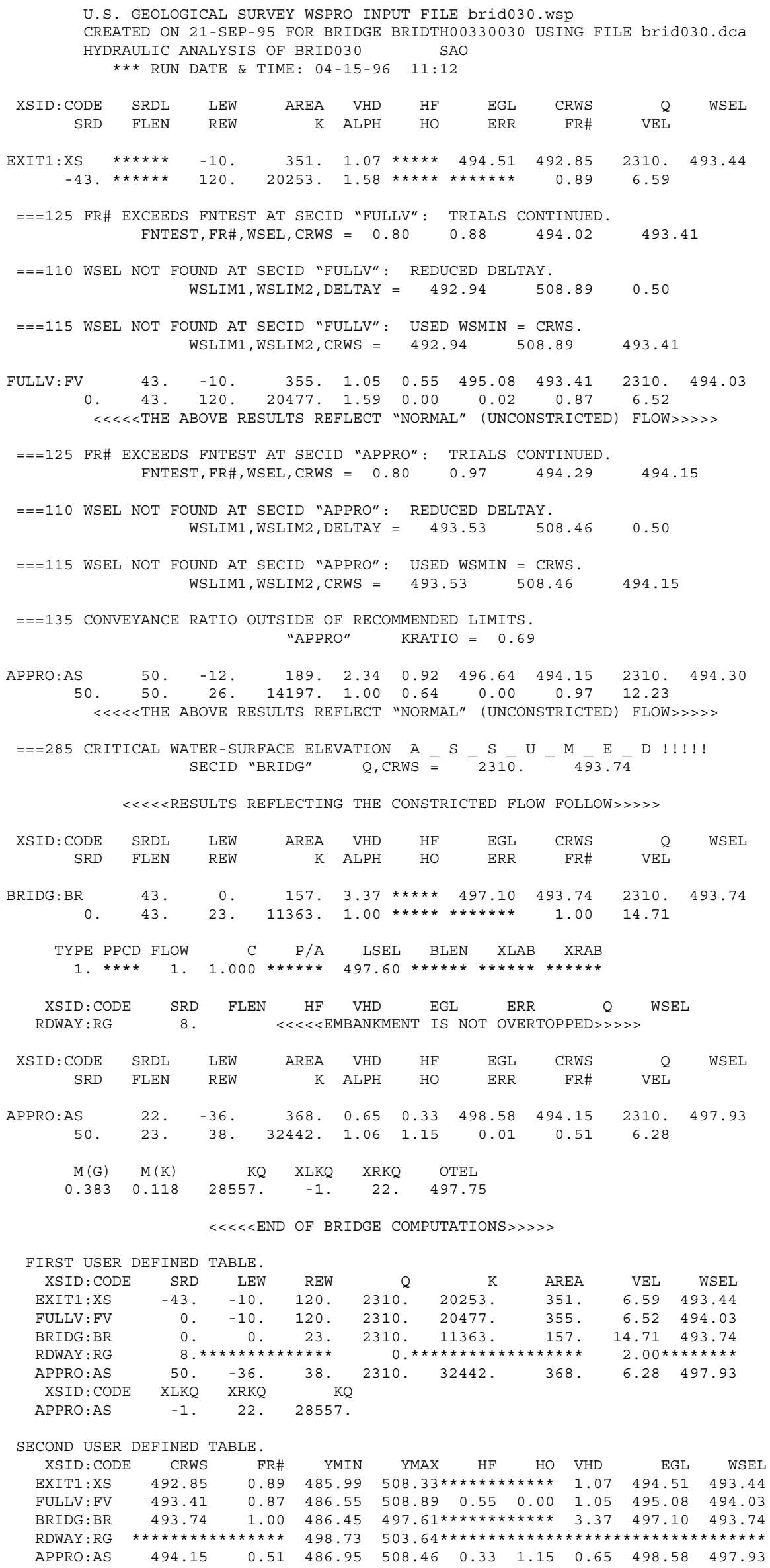




\section{APPENDIX C:}

\section{BED-MATERIAL PARTICAL-SIZE DISTRIBUTION}




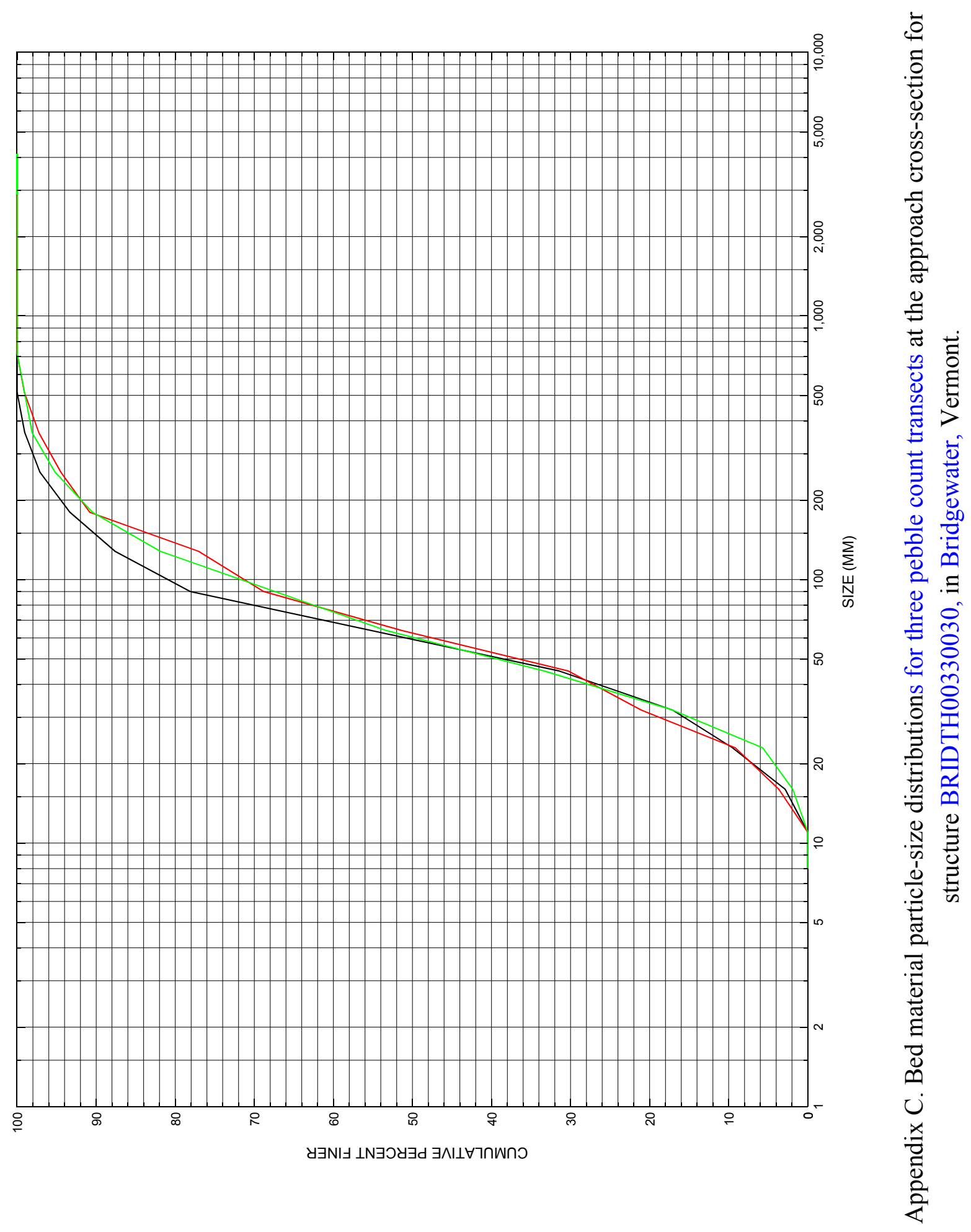




\section{APPENDIX D: \\ HISTORICAL DATA FORM}

